\title{
Harç Tipi Kaplamaların Yüzey Özelliklerinin Sıcak Karışım Asfalt Kaplamalar ile Karşılaştırılması
}

\author{
Ali TOPAL ${ }^{1}$ \\ Mehmet GÜNEŞ² \\ Derya KAYA ${ }^{3}$ \\ Burak ŞENGÖZ ${ }^{4}$
}

ÖZ

Karayolunda güvenli bir sürüşün sağlanabilmesi, yüksek kayma dirençli yüzey dokusuna sahip kaplamalar ile mümkündür. Hizmet ömrü boyunca trafiğin aşındırıcı etkileri, iklim ve çevre koşulları sebebiyle pürüzlülüğünü kaybeden kaplama yüzeylerinin iyileştirilme gerekliliği ortaya çıkmaktadır. Bu çalışma kapsamında, harç tipi kaplama ile iyileştirilmiş ve Bitümlü Sıcak Karışım (BSK) kullanarak yenilenmiş yolların yüzey özellikleri, iyileştirme çalışması öncesi ve sonrasında incelenmiş ve sonuçlar birbirleri ile karşılaştırılmıştır. Çalışma sonuçları, yüzey iyileştirme işlemi yapılan yollarda yüzey dokusu ve buna bağlı olarak sürtünme direnci değerlerinde artış olduğunu göstermiştir. Yüzey iyileştirme uygulamalarının trafik güvenliği üzerinde etkisinin araştırılması için İzmir Trafik Denetleme Şube Müdürlüğü’nden temin edilen kaza verileri analiz edilmiştir. Kaza analiz sonuçları, iyileştirme uygulanan yollardaki kaza miktarlarında önemli oranda azalma meydana geldiğini ortaya koymaktadır. Bununla birlikte BSK kaplamalarda, harç tipi kaplama ve BSK kullanılarak yapılan yüzey iyileştirmelerinin ayrı ayrı 20 yıllık maliyet analizleri yapılmış ve harç tipi kaplama ile yüzey iyileştirmesi yapılmasının BSK'ya göre yaklaşık \%40 daha ekonomik olduğu görülmüştür.

Anahtar Kelimeler: Asfalt kaplama, yüzey dokusu, ortalama doku derinliği, sürtünme direnci, harç tipi kaplamalar, trafik güvenliği.

\section{ABSTRACT \\ Comparison of Slurry Seal and Hot Mixed Asphalt Surface Properties}

It is possible to enjoy a safe road drive on a pavement with a high skid resistant surface texture. During the service life, textures of the pavement surface need to be improved due to

\footnotetext{
Not: Bu yazı

- Yayın Kurulu'na 09.03.2016 günü ulaşmıştır. 06.06.2017 günü yayımlanmak üzere kabul edilmiştir.

- 31 Temmuz 2018 gününe kadar tartışmaya açıktır.
}

- DOI: $10.18400 /$ tekderg. 374650

1 Dokuz Eylül Üniversitesi, İnşaat Mühendisliği Bölümü, İzmir - ali.topal@deu.edu.tr

2 Dokuz Eylül Üniversitesi, Fen Bilimleri Enstitüsü, İzmir - mehmetgunes3636@gmail.com

3 Dokuz Eylül Üniversitesi, İnşaat Mühendisliği Bölümü, İzmir - d.kaya@deu.edu.tr

4 Dokuz Eylül Üniversitesi, İnşaat Mühendisliği Bölümü, İzmir - burak.sengoz@deu.edu.tr 
the corrosive effects of the traffic, climatic conditions and environmental effects. In scope of this study, surface texture properties of different road sections have been evaluated prior to and after the surface improvement by means of a surface rehabilitation application through slurry seal and Hot Mix Asphalt (HMA). The results were then compared. The investigations proved that rehabilitation enhanced the textural properties and hence the frictional values of the surface. In order to investigate the effect of surface enhancement on traffic safety, accident data obtained from the Izmir Traffic Control Branch Directorate were evaluated. These results indicated that there is significant decrease in the number of accidents that occurred after rehabilitation applications. Finally, the cost analysis for both slurry seal and HMA applications has been performed for a period of 20 years. The cost analysis results showed that the surface rehabilitation by means of slurry seal application generally costs $40 \%$ less than the cost of a new HMA application.

Keywords: Asphalt pavement, surface texture, mean texture depth, skid resistance, slurry seal, traffic safety.

\section{GİRiş}

Modern bir karayolu, taşıtların güvenli, konforlu ve ekonomik bir şekilde seyir etmelerine olanak sağlamalıdır. Yol kaplama yüzeyi ile araç tekerleği arasındaki sürtünme direnci, sürüş emniyetini etkileyen önemli bir parametredir. Özellikle olumsuz hava koşullarında kritik öneme sahip olan fren mesafesi, yol yüzey dokusu ile doğrudan etkilenmektedir. Kaplamalar hizmete açıldıktan sonraki kullanım sürecinde trafik tesirleri, iklim koşulları, vb. sebeplerle yüzey dokusu özelliklerini zamanla kaybetmektedir. Güvenli sürüş koşullarının devamı için, kaplamanın yüzey dokusu belirli bir seviyenin altına indiğinde, tekrar başlangıç değerlerine getirebilmek için yüzey iyileştirmesi yapılması gerekmektedir.

Kaplama tabakasının çeşitli sebeplerle deforme olması ve özellikle yol yüzeylerinin cilalanması durumunda mevcut kaplamanın yeniden yapılması yerine, yüzey iyileştirme yöntemlerine başvurulması daha ekonomik bir çözüm olarak öne çıkmaktadır. Özellikle Amerika ve Avrupa'da kaplama yüzeylerinin iyileştirilmesi amacı ile çeşitli yöntemler kullanılmaktadır. Ülkemizde ise iyileştirme yöntemlerinin kullanımı henüz çok yeni olup, genellikle kaplamanın yeniden yapımı tercih edilmektedir. $\mathrm{Bu}$ durum özellikle altyapısı tamamlanmamış kentlerde bakım onarım maliyetlerinin oldukça artmasına neden olmaktadır.

Taşıt kontrolü ve trafik güvenliği büyük oranda kaplama yüzey özelliklerine bağlıdır. Sürücü fren tedbirine başvurduğunda, yol yüzeyi ile tekerlek bandajları arasında hem kuru ve hem de yağışlı hava koşullarında gerekli aderans sağlanmalıdır. Taşıt tekerleği ile kaplama arasındaki yetersiz aderans patinaj, savrulma, kayma, fren mesafesinde artış gibi tehlike oluşturabilecek durumları da beraberinde getirmektedir.

Karayolları Genel Müdürlüğü (KGM) Yollar Teknik Şartnamesi 2013 yılında güncellenmiş ve yeni yapılan yollarda kum yama deneyi ile yol yüzeylerinin makro dokusunun belirlenmesi şartı getirilmiştir. $\mathrm{Bu}$ doğrultuda çalışma kapsamında, yol yüzeylerinin makrodokusunun belirlenmesinde kum yama deney yöntemi kullanılmıştır. Kaplama yüzeylerinin kayma dirençlerinin ölçülmesinde ise Yollar Teknik Şartnamesinde bir kriter bulunmamakla birlikte, gelişmiş ülkelerde kayma dirençlerinin ölçülmesinde SRT (Skid Resistance Test: Kayma direnci ölçer) yöntemlerinden biri olan DFT (Dynamic Friction 
Tester: Dinamik sürtünme ölçer) yaygın olarak kullanılmaktadır. Bu nedenle, DFT cihazı bu çalışma kapsamında kayma direnci ölçümünde kullanılmıştır.

Çalışma kapsamında saha ölçümlerinin yapıldığı yollar, İzmir Büyükşehir Belediyesi'nce İzmir ilinde yüzey iyileştirme yöntemlerinden harç tipi kaplamanın ilk defa uygulandığ yol kesimleri olup, başlıca amaç, harç tipi kaplamalarda yüzey doku özelliklerinin zamanla nasıl değiştiğini gözlemlemek ve sıcak asfalt karışımların (BSK) yüzey özellikleri ile karşılaştırmaktır. Belirlenen istasyon noktalarının konumları, yol kaplamalarında kullanılan malzemelerin özellikleri ve trafik akım karakteristikleri tanımlanarak, arazi çalışmaları sonrasında yapılacak değerlendirmeler için mevcut durum tespiti yapılmıştır. Çalışma kapsamında, üç farklı istasyon noktasında, benzer hava koşullarında yaklaşık 3'er aylık periyotlar halinde kum yama yöntemi ile yol yüzey makrodokusu; DFT cihazı ile $20 \mathrm{~km} / \mathrm{saat}$ hıza karşılık gelen değer DFT(20) olarak belirlenerek dinamik sürtünme direnci olarak kaydedilmiştir. Ortalama doku derinliği kullanılarak hesaplanan sürtünme sabiti (Sp) ile birlikte DFT(20) değerleri kullanılarak hıza bağlı değişen Uluslararası Sürtünme İndeksi (IFI: International Friction Index) değerleri $60 \mathrm{~km} /$ saat için hesaplanmıştır (FR(60)).

Çalışma kapsamında ayrıca, yüzey dokusu ve kayma direnci özelliklerinin trafik güvenliğine etkisinin incelenebilmesi için İzmir Trafik Denetleme Şube Müdürlüğ̈̈'nden, seçilen istasyon noktalarında yaşanan kaza istatistikleri temin edilerek ayrı ayrı ölçüm dönemleri bazında değerlendirilmiştir. Son olarak harç tipi kaplama ve BSK için hizmet ömrünü esas alan 20 yıllık maliyet analizi yapılarak, harç tipi kaplamalarla daha ekonomik ve güvenli iyileştirme yapılıp yapılamayacağının İzmir İlinde seçilen istasyon noktaları özelinde belirlenmesi amaçlanmıştır.

\section{LITERATÜR ÖZETI}

Kayma direnci, araç lastikleri ve yol kaplama yüzeyleri arasında oluşan sürtünmeye bağlı yol güvenliğine katkıda bulunan en önemli faktörlerden biridir [1, 2]. Sürücülerin araç kullanım özelliklerini ve duruş mesafesini etkileyen bu faktör, zaman içerisinde kaplama yüzeyindeki agregaların aşınmasından dolayı azaldığı için kaplamaların yenilenmesi ya da iyileştirilmesi gerekir. Kaplamaların sıcak asfalt karışımları ile bakım onarımlarının yapılması yüksek maliyetlere neden olmakta ve üretim hataları ile kot farklılıkları hem onarım yapılmış kaplamanın beklenenden daha çabuk bozularak yapılan harcamaların heba olmasına neden olmakta, hem de konforu bozmaktadır. Literatürde, kaplama iyileştirme yöntemlerinin etkinlikleri ile ilgili birçok çalışma yapılmış ve bu yöntemlerin avantaj ve dezavantajları üzerinde durulmuştur $[3,4]$. Bu iyileştirme yöntemleri arasında harç tipi kaplamalar avantajları ile ön plana çıkmaktadır. Ancak harç tipi kaplamaların yüzey özellikleri ile ilgili literatürde bir araştırmaya rastlanmamıştır. Harç tipi kaplama, asfalt emülsiyonunun sürekli gradasyonlu ince agrega, filler ve su ile homojen karıştırılmasıyla elde edilen ve kaplama yüzeylerinin koruyucu ve düzeltici bakımında kullanılan ince bir yüzeysel örtü tabakasıdır.

Kaplama yüzeyindeki kayma direnci genellikle karışımda kullanılan agreganın minerolojik kompozisyonuna, morfolojisine ve mekanik özelliklerine bağlıdır. Kaplama yüzeyinin yeterli ve uzun süreli kayma direncine sahip olması için yol yüzey tabakasının agrega bileşenlerini optimize etmek gerekmektedir. Kaplama yüzey dokuları şu şekilde sınıflandırılabilir; 
- Mikrodoku, karışımdaki agrega yüzeyindeki pürüzlülüğe bağlıdır (Dalga boyu $0,5 \mathrm{~mm}$ 'den genliği $0,2 \mathrm{~mm}$ 'den düşük girinti ve çıkıntılar).

- Makrodoku, agreganın dane boyutuna ve şekline bağlı bir parametredir (Dalga boyu 0,5-50 mm, genliği 0,2-10 mm arasında değişen girinti ve çıkıntılar). Makrodoku özellikle kaplamanın sürtünme direnci üzerinde etkilidir.

- Megadoku, yol yapım aşamasında finişerin vibrasyonu sonucunda veya yol yüzeyinin zamanla bozulması sonucu oluşan çatlaklar, tekerlek izleri gibi kalıcı deformasyonlar vb. nedenlerle ortaya çıar (Dalga boyları $50-500 \mathrm{~mm}$, Genlikleri 10-50 $\mathrm{mm}$ arasında değişen girinti ve çıkıntılar). Megadoku, sürüş konforunu bozan bir özellik olup, mikrodoku ve makrodokudan farklı olarak kaplamalarda istenilen bir yüzey özelliği değildir.

Islak yol yüzeyleri üzerinde birikmiş suyun yol yüzeyinden ayrılması için doku derinliğinin belirli değerlerde olması gerekmektedir [5]. Doku derinliği bir yüzey alanı için lastik/yol yüzey ara fazının üç boyutlu hali veya bir mesafe için lastik/yol yüzey arafazının iki boyutlu hali olarak aşağıdaki şekillerde tanımlanmaktadır [6].

- Doku Derinliği (Texture Depth), TD; Yüzey ile yüzeyde en büyük üç pik noktasından geçen düzlem arasındaki düşey mesafe,

- Ortalama Doku Derinliği (Mean Texture Depth), MTD: Hacim esasına dayanan kum yama yöntemi kullanılarak kaplamanın ortalama makro derinliği.

Yol Kongreleri Daimi Birliği (PIARC) tarafından desteklenen ve farklı üye ülkelerdeki farklı tipteki yol yüzeylerinin, modern yol yüzey dokusu ve sürtünme direnci aletleri ile ölçümü planlanmış ve ölçümlerin sonuçları değerlendirilerek uluslararası sürtünme direnci indeksi oluşturma çalışmaları yapılmıştır. Sürtünme direncini tespit etmek amacı ile kilitlenmiş tekerlek, sabit ve değişken kayma aletleri, dinamik sürtünme ölçer test cihazı ile bazı prototip cihazlar kullanılmıştır. Yol doku derinlikleri için ise kum yama, lazer profilometresi ve bazı optik sistemler kullanılmıştır. Çalışmalar sonunda, Uluslararası Sürtünme İndeksi (IFI) kaplama yüzeylerinin sürtünme özelliklerinin sınıflandırılabilmesi için ortak bir referans ölçek olarak geliştirilmiştir. IFI, kaplama makro yapısının hız sabiti ile ilişkilendirildiği PIARC sürtünme modeli olarak tanımlanan bir istatistiksel modeldir [7].

Yüzey dokusu ve kayma direncindeki azalma, yol yüzeyinin araç lastikleri ile yaptı̆̆ 1 aderansı azaltmaktadır. Bu durumda özellikle yağışlı havalarda fren mesafesi uzamakta ve buna bağlı olarak yol sürüş güvenliği azalmaktadır. Bu alandaki çalışmalar, sürtünme direncindeki azalmanın trafik kazalarını arttırdığını ortaya koymaktadır $[8,9,10]$.

Kaplama yenileme yöntemlerinden olan BSK ve harç tipi kaplama üretimlerinin performans özellikleri ile birlikte yaşam ömürleri ve üretim maliyetleri de farklıdır. Bu iki kaplama yönteminin yaşam ömürleri birçok araştırmaya konu olmuştur. Trafik hacimleri, yükleme koşulları ve çevresel faktörlere de bağlı olmakla birlikte, harç tipi kaplamanın yaklaşık 3-4 yıl, BSK'nın ise 9-10 yıl hizmet ömrü olduğu öngörülmüştür [11,12]. 


\section{SAHA CALISSMALARI}

\section{1. İstasyon Noktalarının Belirlenmesi}

İzmir Büyükşehir Belediyesi tarafından 2013 yılında bazı kritik yol kesimlerinde harç tipi kaplama ile yüzey iyileştirmesi yapılmıştır. Bu nedenle çalışma kapsamında harç tipi kaplamaların performansının incelenebilmesi ve önce-sonra etütlerinin yapılabilmesi için TÜBİTAK MAG 108M293 [13] projesi kapsamında daha önce incelenen istasyon noktaları arasından harç tipi kaplama yapılan istasyon noktaları deneysel çalışmalar yapılmak üzere seçilmiş̧ir. Seçilen istasyon noktalarına ek olarak, Harç Tipi Kaplamanın yüzey performans özelliklerinin karş̧laştırabilmesi için BSK kullanılarak iyileştirilmiş bir istasyon noktası da seçilmiştir. BSK tasarımında, İzmir Aliağa Rafinerisi'nden temin edilen 50/70 penetrasyonlu asfalt çimentosu \%4,76 toplam karışım oranında kullanılmıştır. Agrega olarak Karayolları Teknik Şartnamesinde (KTŞ) yer alan aşınma Tip-1 gradasyonuna sahip kalker kullanılmıştır.

Seçilen istasyon noktalarının trafik güvenliği açısından kavşak ve benzeri kesişim noktalarından mümkün olduğunca uzakta olmasına dikkat edilmiştir. Ölçümler, yol malzemeleri ve deney ekipmanlarında meydana gelebilecek iklimsel etkileri (lastik bapuçun sertliği, su sıcaklığı, kum küreciklerinin uçması, vb.) minimize etmek amacıyla benzer hava ve sıcaklık koşullarında gerçekleştirilmiştir (Çizelge 1).

Çizelge 1. Ölçüm isimleri ve tarihleri

\begin{tabular}{|c|r|}
\hline Ölçüm İsmi & Ölçüm Tarihi \\
\hline $2014 / 1$ & 06.02 .2014 \\
\hline $2014 / 2$ & 01.04 .2014 \\
\hline $2014 / 3$ & 01.10 .2014 \\
\hline $2014 / 4$ & 25.12 .2014 \\
\hline $2015 / 1$ & 29.04 .2015 \\
\hline
\end{tabular}

Çalışma kapsamında Yeşildere Caddesi ve Mustafa Kemal Sahil Bulvarı üzerinde 4'er adet istasyon noktası seçilmiştir.

\subsubsection{Yeşildere Caddesi}

Yeşildere Caddesi, şehrin kuzeyinden Altınyol ve Ankara Caddesi ile gelen trafiği Mürselpaşa Caddesi ile toplayarak, Yeşillik Caddesi ile şehrin güneyine aktarılmasını sağlayan yaklaşık $4,5 \mathrm{~km}$ uzunluğunda ve $25 \mathrm{~m}$ platform genişliğinde bir yoldur. Yeşildere Caddesi'ne ait genel görünüm ve ölçüm yapılan istasyon noktaları Şekil 1'de gösterilmiştir. Yeşildere Caddesi üzerindeki 1, 2 ve 3 No'lu istasyonlar harç tipi kaplama 4 No'lu istasyon ise BSK kaplamalıdır. 


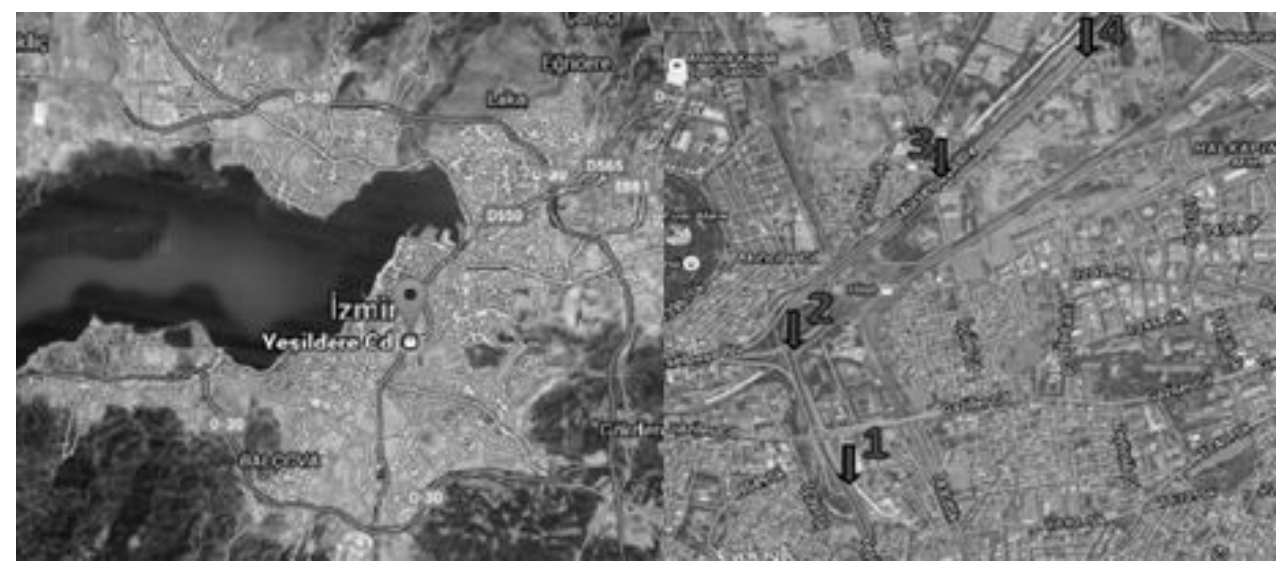

Şekil 1. Yeşildere genel görünüm ve ölçüm yapılan istasyon noktaları

\subsubsection{Mustafa Kemal Sahil Bulvart}

Mustafa Kemal Sahil Bulvarı, İzmir Körfezi'nin güney sahil şeridi boyunca devam eden, 6,2 $\mathrm{km}$ uzunluğunda ve $27 \mathrm{~m}$ platform genişliğinde bir yoldur. Bu yol, Cumhuriyet Bulvarı ile Fevzipaşa Caddesi'nin kesiştiği noktadan başlayarak, İzmir-Çeşme Otoyolu'na bağlanmaktadır. Mustafa Kemal Sahil Bulvarı (Konak Altgeçidi) istasyon noktalarına ait genel görünüm ve ölçüm yapılan istasyon noktaları Şekil 2'de gösterilmiştir. Mustafa Kemal Sahil Bulvarı üzerindeki 1, 2 ve 3 No'lu istasyonlar harç tipi kaplama 4 No'lu istasyon ise BSK kaplamalıdır.

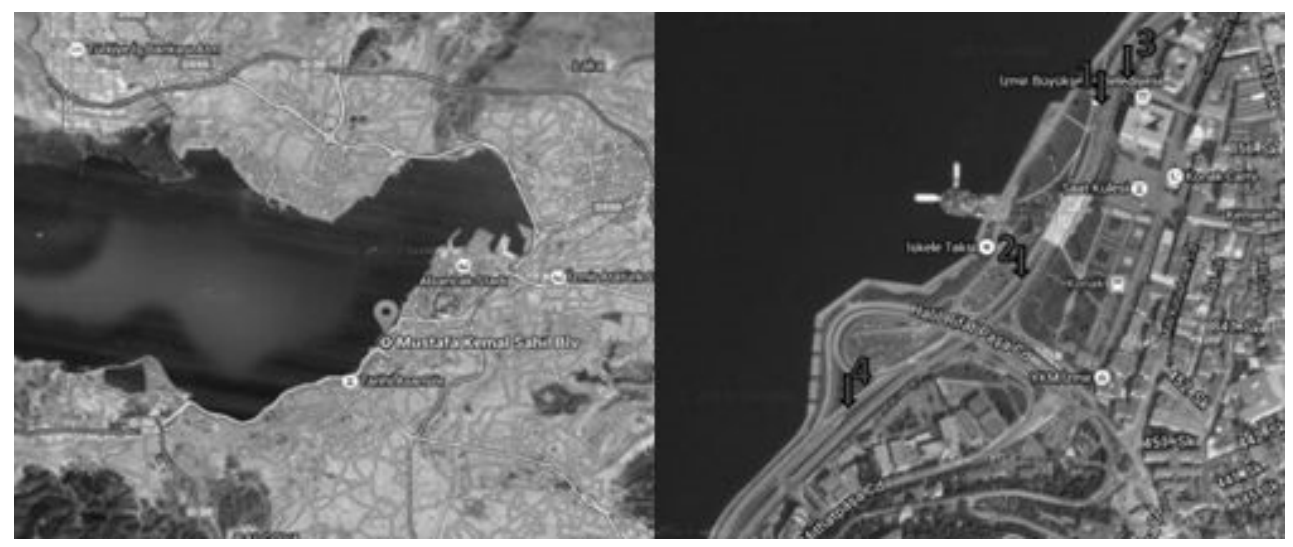

Şekil 2. Mustafa Kemal Sahil Bulvarı genel görünüm ve ölçüm yapılan istasyon noktaları

\subsection{Dinamik Sürtünme Ölçer Testi}

Dinamik sürtünme ölçer (DFT), saha ve laboratuvar ölçümlerinde kalite kontrol/kalite güvencesi, proje ve araştırmalarda yararlanılmak üzere sürtünme verilerinin elde edilmesi 
için kullanılmaktadır. Deney yöntemi ASTM E 1911'de belirtilmiştir [14]. Şekil 3'de gösterildiği gibi 3 adet kauçuk lastik yatay dönen diskin altına sabitlenmiştir. Cihaz çalışmaya başladıktan sonra disk dönmeye başlar ve $80 \mathrm{~km} / \mathrm{saat}$ hıza ulaştığında otomatik olarak kaplama yüzeyine dik bir şekilde alçalarak yola temas eder. Kauçuk lastikler yol yüzeyine dik bir şekilde etkiyen $\mathrm{W}$ sabit yükü altında ve doğrusal bir F kuvveti ile V hızında döner. F değeri ile sabit oranda artan $\mu$ sürtünme değeri 20,40 , 60 ve $80 \mathrm{~km} / \mathrm{saat}$ hiz değerlerinde hesaplanır. Bu yöntem, her aşamada tekrar edilebilme ve yeniden yapılabilme imkânı sunmakla birlikte, rüzgar, hatalı okuma gibi dış etkenlerden kesinlikle etkilenmeden uluslararas1 kayma direnci indeksi (IFI-ASTM E1960-07) değerine kolayca ulaşılabilmektedir [17].

Dinamik sürtünme ölçer cihazı, tüm eğrileri tek bir sürtünme eğrisi olarak değerlendirmekte ve Şekil 4'de gösterildiği gibi hıza bağlı değişimi vermektedir. Deney 0 ile $80 \mathrm{~km} / \mathrm{saat}$ arasındaki hızlardan IFI değerinin elde edilmesinde kullanılan $20 \mathrm{~km} / \mathrm{saat}$ hıza karşılık gelen DFT verisini esas almaktadır.
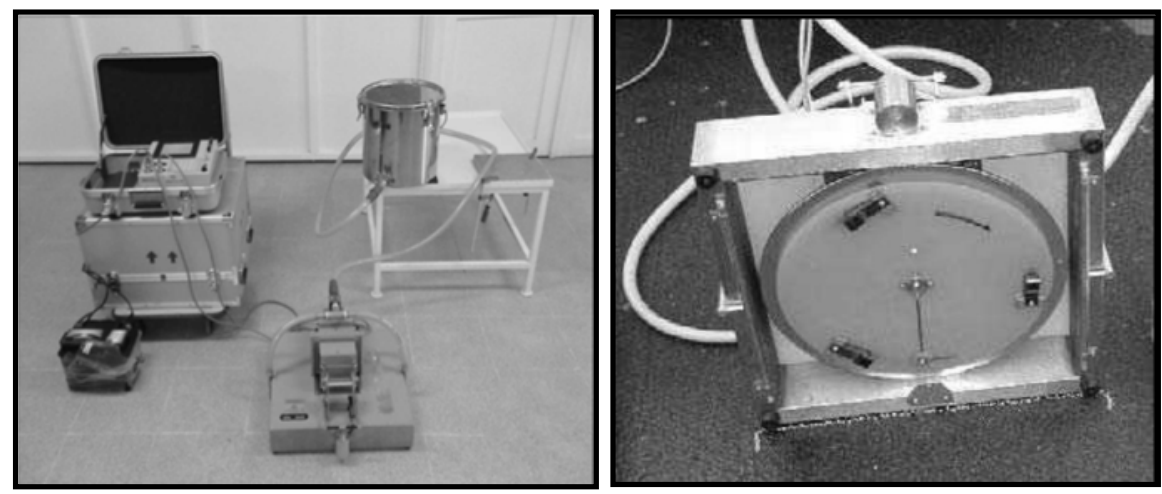

Şekil 3. Dinamik sürtünme ölçer test cihazı

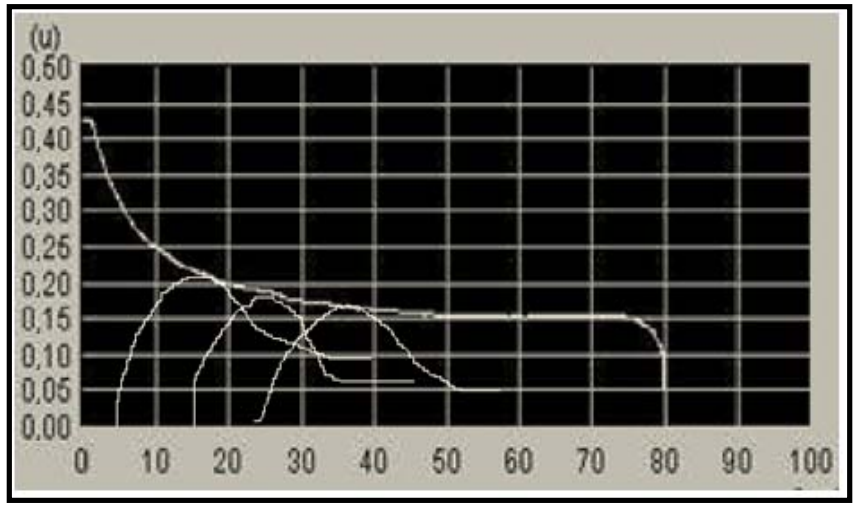

Şekil 4. Hıza bağlı DFT dĕgerinin genel değişimi 


\subsection{Kum Yama Yöntemi (ASTM E 965-96)}

İngiltere'de geliştirilen bu deneyin amacı, yol yüzey doku derinliğini belirlemektir. Boyutları standartlaştırılmış ve hacmi bilinen bir miktar kum (British Standard 598'e göre $50 \mathrm{ml}$ ) kaplamanın girintilerini dolduracak, çıkıntılarını aşmayacak şekilde, bir kauçuk ayak yardımıyla, yüzey üzerine dairesel olarak yayılır. İşlem sonucunda kaplama yüzeyinin ortalama doku derinliği elde edilmiş olur. Kullanımı pratik olan bu yöntemin ıslak koşullar altında kullanımının zor olması, zayıf üretilebilirlik ve doku derinliği az olan yollarda doğru veri vermemesi gibi dezavantajları vardır.

\subsection{Sürtünme İndeksi}

DFT kullanarak kaplamanın sürtünme özellikleri Denklem 1'deki gibi ifade edilmektedir.

$$
F R(V)=D F T_{20} \times e^{\frac{-V+20}{S p}}
$$

Burada;

$\mathrm{DFT}_{20}=20 \mathrm{~km} /$ saat hıza karşılık gelen dinamik sürtünme değeri.

$\mathrm{V}=$ Taşıt hızı $(\mathrm{km} / \mathrm{saat})$

$\mathrm{Sp}=$ Sürtünme Sabiti (Speed constant).

IFI'yı oluşturan temel parametrelerden biri olan ve kaplama yüzeyinin cilalanma özellikleri ile ilgili bilgi veren Sp değeri, yolun ortalama profil derinliği veya ortalama doku derinliği ile ilişkilidir ve aşağıdaki eşitlik ile hesaplanmaktadır.

$\mathrm{Sp}=\mathrm{a}+\mathrm{b} \times \mathrm{T}$

Denklem 2'deki a ve b sabit katsayılar olup ASTM E 965 (Kum yama yöntemi) ile tayin edilecekse veya ASTM E 1845 ile tayin edilecekse farklı değerler almaktadırlar. Çalışma kapsamında Sp değeri MTD’nin bir fonksiyonu olarak Denklem 3'deki gibi kullanılmıştır.

$\mathrm{Sp}=-11,6+113,6 \times \mathrm{MTD}$

IFI'yi oluşturan diğer parametre ise F(60)'tır. Bu değer $60 \mathrm{~km} /$ saat hızdaki normalleştirilmiş sürtünme değeridir ve Denklem 4'deki gibi hesaplanır.

$$
F R(60)=D F T_{20} \times e^{\frac{-60+20}{S p}}
$$

Burada;

$\mathrm{FR}(60)=\mathrm{S}$ kayma hızında $60 \mathrm{~km} /$ saat hıza göre hesaplanmış düzeltilmiş sürtünme değeri, 
$\mathrm{FR}(\mathrm{S})=\mathrm{S}$ kayma hızındaki sürtünme değeri (DFT ile)

$\mathrm{S}=$ Kayma hızı, km/saat (genellikle $20 \mathrm{~km} /$ saat alınmaktadır)

Uluslararası sürtünme indeksi çalışmaları kapsamında ele alınan bağıntı ise aşağıdaki denklemde ifade edilmiştir.

$$
F(V)=A+B \cdot F R(V)
$$

Burada;

$\mathrm{F}(60)=$ Düzeltilmiş IFI sürtünme sayısı

A, B = Sürtünme ölçüm aletine bağlı kalibrasyon sabiti (DFT cihazı icin bu parametreler $\mathrm{A}=0,11 ; \mathrm{B}=0,66$ olarak ilgili ASTM standardından alınmıştır)

Sp ve $60 \mathrm{~km} /$ saat hızdaki sürtünme değeri bilinen bir kaplamanın herhangi bir S kayma hızındaki sürtünme değeri tahmin edilebilir. Şekil 5'deki IFI model grafiği Denklem 6 kullanılarak elde edilmiştir ve herhangi bir S kayma hızının $F(60)$ ve Sp değerlerinin tahmininde kullanılabilir $[6,15,16]$.

$$
F N(S)=F N v \times e^{\frac{(S-V)}{S p}}
$$

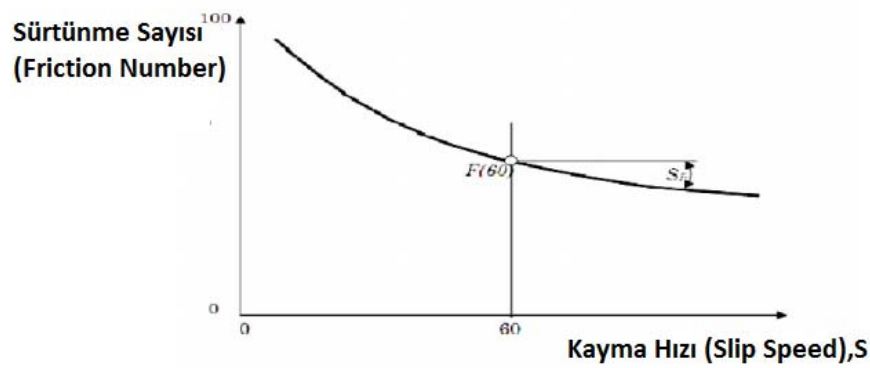

Şekil 5. Uluslararası kayma indeksi Modeli (IFI)

\section{VERILERIN DEĞERLENDİRILMESI}

\subsection{Dinamik Sürtünme Ölçer Testi Sonuçları}

Yeşildere Caddesi ile Mustafa Kemal Sahil Bulvarı İstasyon noktalarında (1, 2 ve 3 no'lu) Dinamik Sürtünme Ölçer Test Cihazı ile 2013 yılında yapılan kaplama iyileştirme çalışması öncesi ve sonrası ölçüm dönemlerinde kaplamaların DFT20 değerleri Şekil 6 ve 7'de sunulmuştur. Şekil 6 ve 7'de harç tipi kaplama yapıldıktan sonraki dönemlerdeki DFT 20 değerleri BSK ile kıyaslamalı olarak verilmiştir. 


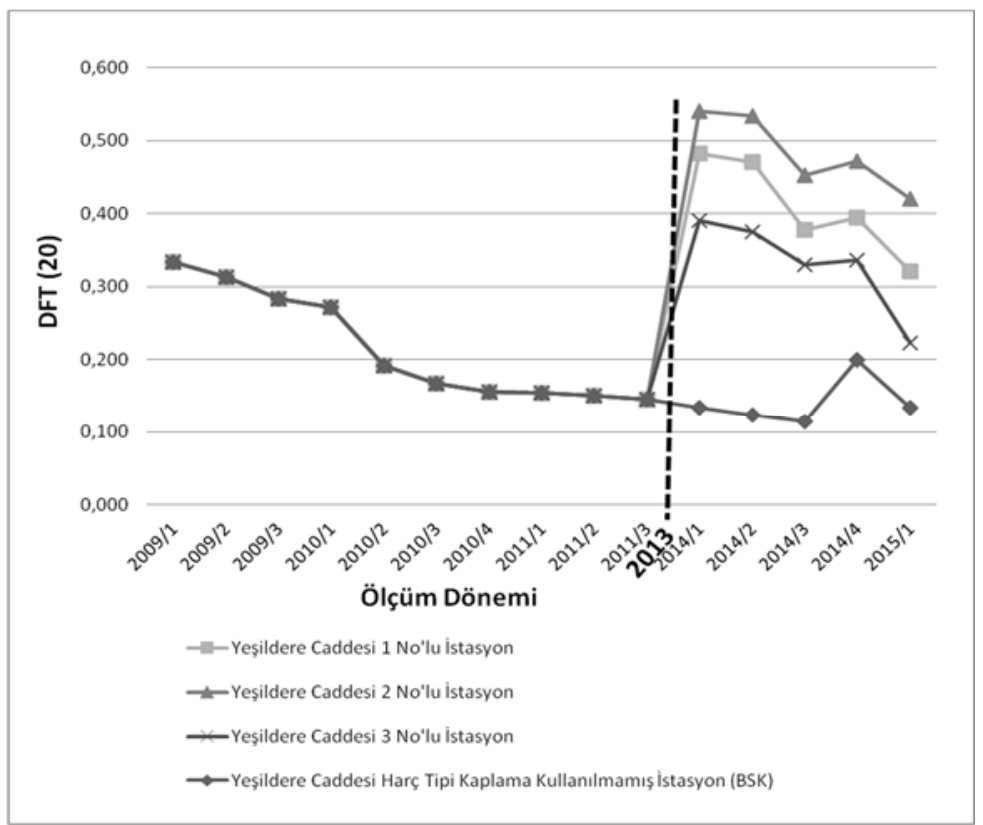

Şekil 6. Yeşildere Caddesi istasyonlarının ölçüm dönemlerine göre DFT20 değişimi

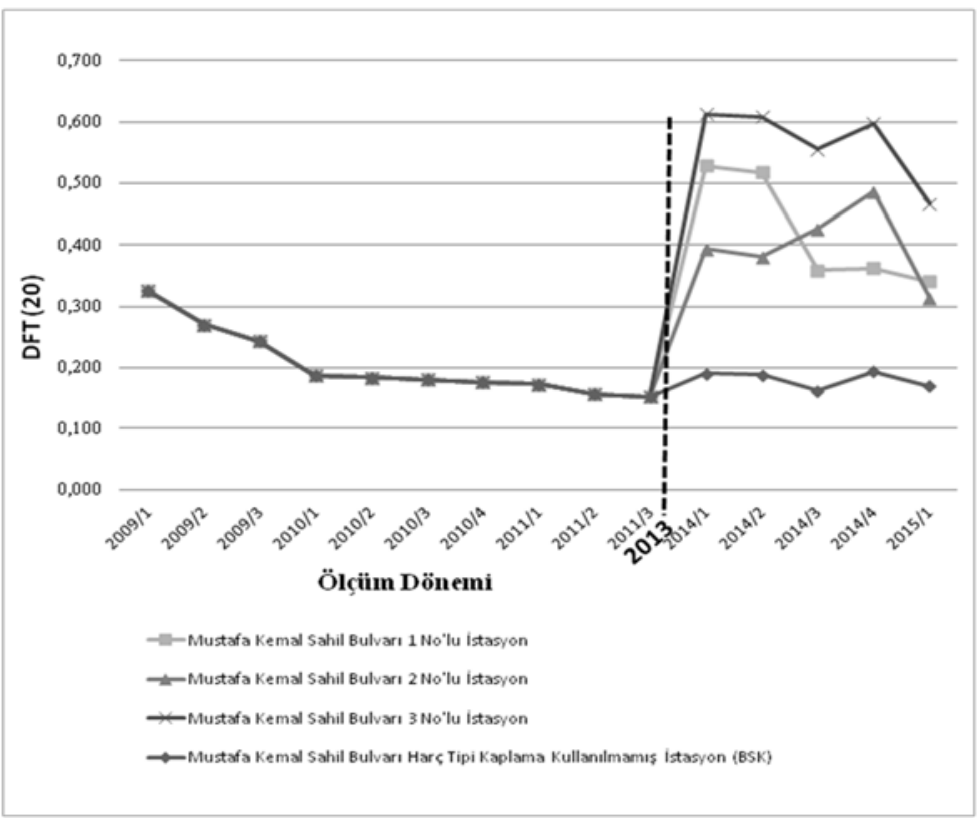

Şekil 7. M. Kemal Sahil Bulvarı istasyonlarının ölçüm dönemlerine göre DFT20 değişimi 
DFT, kaplamanın sürtünme direnci hakkında fikir veren dinamik sürtünme katsayısının ölçülmesini sağlamaktadır. Yukarıdaki şekillerde de açıkça görüleceği gibi $20 \mathrm{~km} / \mathrm{saat} \mathrm{hıza}$ karş1lık gelen sürtünme değeri DFT20 tüm ölçüm dönemleri boyunca beklenildiği şekilde azalma eğilimindedir. Bu durum doğrudan yoğun trafik etkisi ile zaman içerisinde azalan sürtünme direnci ile açıklanabilir. 2013 yılında harç tipi kaplama kullanılarak yapılan yüzey iyileştirme işleminden sonra DFT20 değeri beklenildiği üzere artış göstermiştir.

Bununla birlikte yeni yapılan harç tipi kaplama ile BSK kaplama arasında karşılaştırma yapıldığında; 2014/1 dönemi için harç tip kaplamanın DFT20 değerinin BSK kaplamanın DFT20 değerinde göre 1,6 ile 2,8 kat daha fazla olduğu, bu oranların 2015/1 son ölçüm döneminde azaldığı görülmektedir. Bu durum kaplama yüzeylerinde yüzey dokusu azaldıkça DFT20 değerlerinin birbirlerine yaklaştığını göstermektedir.

Ayrıca 2014/4 ölçüm döneminde tüm kaplama yüzeyleri için DFT20 değerlerinin bir önceki ölçüm dönemine göre bir miktar arttığı gözlenmiştir. Bu durum, özellikle yoğun yağış dönemlerinde kaplama yüzeyinin çok iyi yıkanması ve yüzey dokusunun ortaya çıkması ile açıklanabilir. Yüzeysel toz ve çamurların kaplama yüzeylerinin makro dokusunu doldurması sonucu DFT20 değerleri artış şeklinde değişim gösterebilmektedir. Bu durum, deney sonuçlarının mevsimsel farklılıklara ve özellikle yağışlara duyarlı olduğu sonucunu ortaya koymaktadır.

\subsection{Kum Yama Yöntemi (ASTM E 965-96) Sonuçları}

Şekil 8 ve 9'da sırasıyla Yeşildere Caddesi'ndeki ve Mustafa Kemal Sahil Bulvarı'ndaki istasyon noktalarının 2013 yılında yapılan yenileme çalışması öncesi ve sonrası tüm ölçüm dönemlerine ait ortalama doku derinliklerindeki (MTD) değişimler verilmiştir.

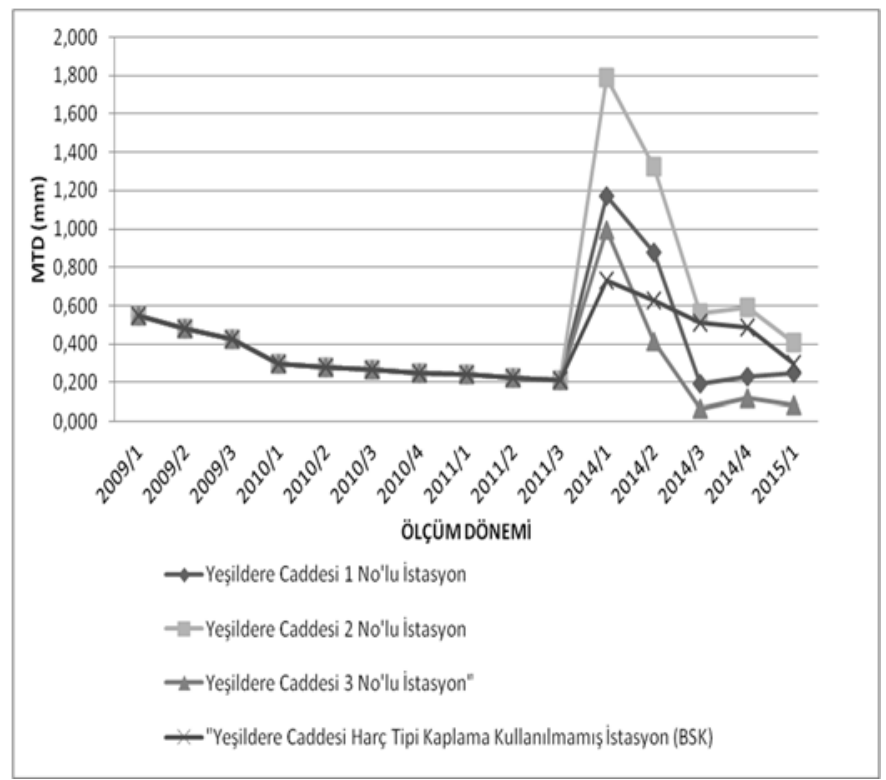

Şekil 8. Yeşildere Caddesi kum yama deneyi ile ortalama doku derinlikleri (MTD) 


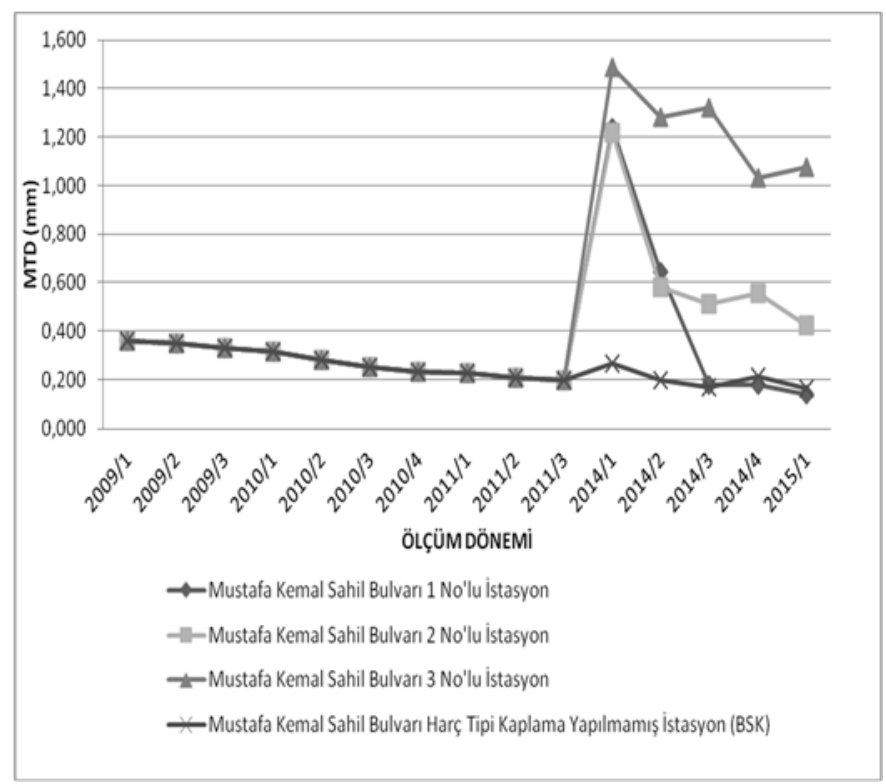

Şekil 9. M. Kemal Sahil Bulvarı kum yama deneyi ile ortalama doku derinlikleri (MTD)

Kum yama yöntemi, yüzeyin ortalama doku derinliklerini (MTD) ölçmekte kullanılan bir yöntemdir. Tüm ölçüm dönemleri göz önüne alındığında MTD değerlerinin tüm istasyon noktalarında zamanla azalma eğiliminde olduğu belirlenmiştir. $\mathrm{Bu}$ azalma, kaplama üzerinden zamana bağlı olarak eklenik araç sayısının artması ve yüzeyi aşındırmasıyla azalan doku derinliği ile açıklanabilir. 2013 yılında gerçekleştirilen yenileme işleminden sonra kaplamaların MTD değerleri önemli oranda artmıştır.

\subsection{Sürtünme İndeksi Sonuçları}

Şekil 10 ve Şekil 11'de Yeşildere Caddesi ve Mustafa Kemal Sahil Bulvarı istasyon noktalarına ait $60 \mathrm{~km} / \mathrm{saat}$ hız değerine karşılık gelen IFI sürtünme eğrileri $\mathrm{F}(60)$ yer almaktadır.

F(60) değerleri, hem doku derinliğine hemde DFT20 değerlerine bağlı olarak hesaplandığ için şekillerde ölçüm dönemleri boyunca $\mathrm{F}(60)$ değerleri azalma eğilimi göstermiştir. $\mathrm{Bu}$ durum trafik etkisi ile ölçüm dönemleri boyunca MTD'de azalma ile birlikte lastik-taşıt etkileşimini ifade eden DFT20 değerlerindeki azalmaya bağlıdır. Sunulan iki şekilde de 2013 yılında istasyon noktalarında uygulanan yüzey iyileştirme yöntemlerinden olan harç tipi kaplamanın sürtünme direncini arttırdığı açıkca görülmektedir. 


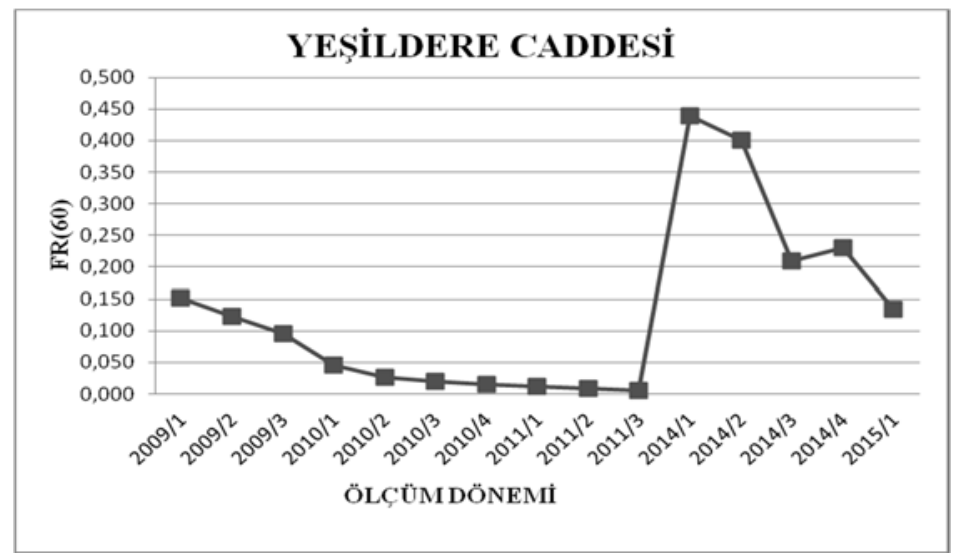

Şekil 10. Yeşildere Caddesi uluslararası sürtünme indeksi ĕgrileri (FR(60))

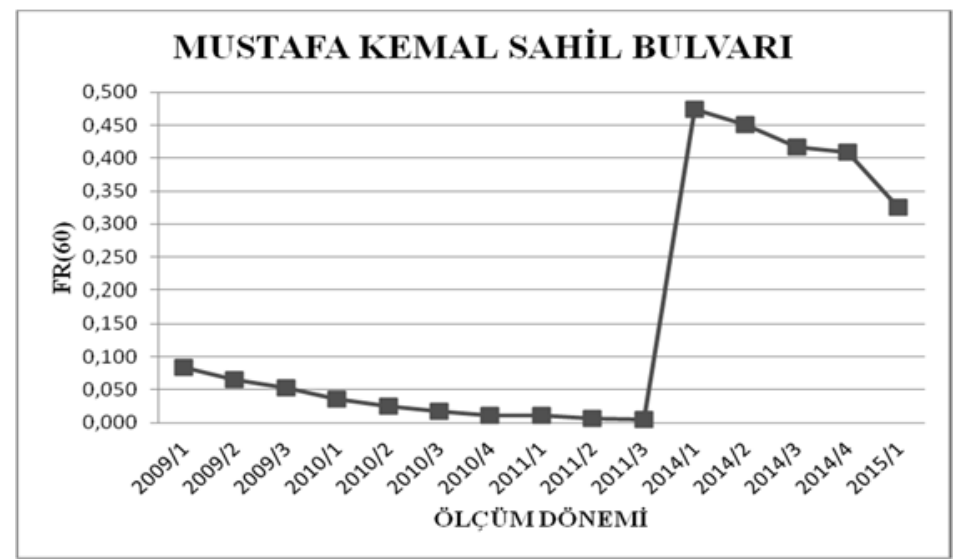

Şekil 11. M.Kemal Sahil Bulvarı uluslararası sürtünme indeksi eğrileri (FR(60))

\subsection{Kaza Analizleri}

Harç tipi kaplamaların sağladığı yüksek sürtünme direncinin trafik kazaları ve yol güvenliğine etkisini incelemek amacıyla çalışma kapsamında, İzmir Trafik Denetleme Şube Müdürlügü̈'nden 2010, 2011, 2012, 2013, 2014, 2015 y1llarına ait ölümlü, yaralanmalı, kamu araçlarının karıştığı kazalar ile tek araçların karıştığı kaza verileri temin edilmiştir.

Yeşildere Caddesine ilişkin kaza verilerinin ayrıntılı analizleri sırasıyla Yeşildere Caddesi ve Mustafa Kemal Sahil Bulvarı için Şekil 12 ve 13'de verilmiştir.

İzmir Trafik Denetleme Şube Müdürlüğ̈̈’nden alınan veriler incelendiğinde 2013 yllında yapılan yenileme işleminden önce gerçekleşen kaza sayılarının zaman içerisinde arttığ görülmüsstür. Kaplamanın zaman içerisinde azalan sürtünme direnci ve yüzey pürüzlülüğünün fren mesafelerini arttırması ve kaplamayı daha güvensiz hale getirmesi buna 
sebep olarak gösterilebilir. Her iki istasyon noktasında da 2013 yılından sonra yapılan yenileme işlemi ile birlikte gerçekleşen kazalar da incelendiğinde ise kaza oranlarında fark edilir bir azalma olduğu görülmüştür. Böylece, yenileme işlemi yapılan kaplamaların kaza oluşumu açısından daha güvenli olduğunu söylemek mümkündür.
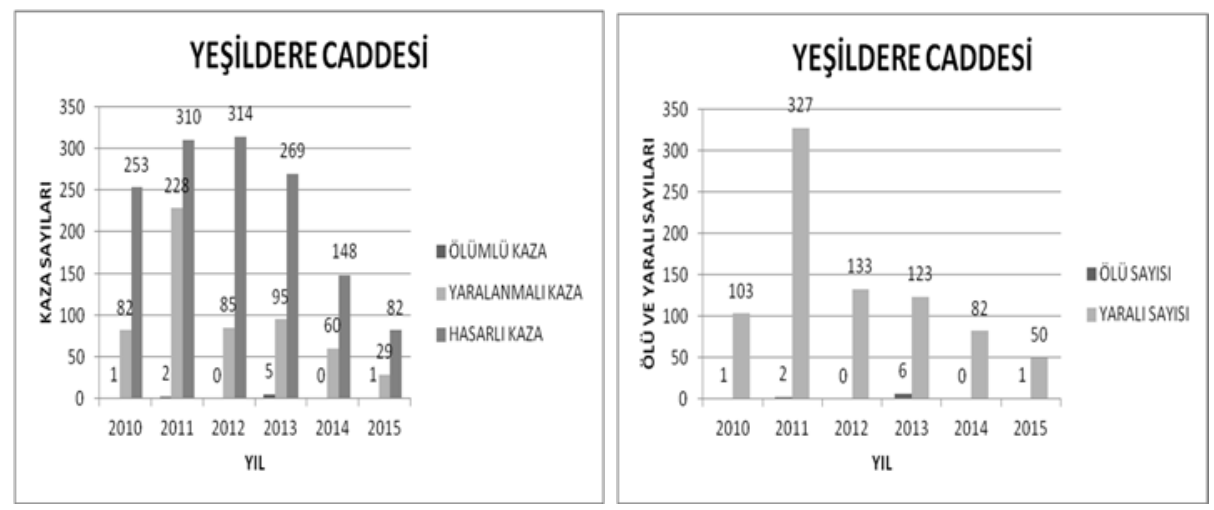

Şekil 12. Yeşildere Caddesi'ne ait kaza verileri
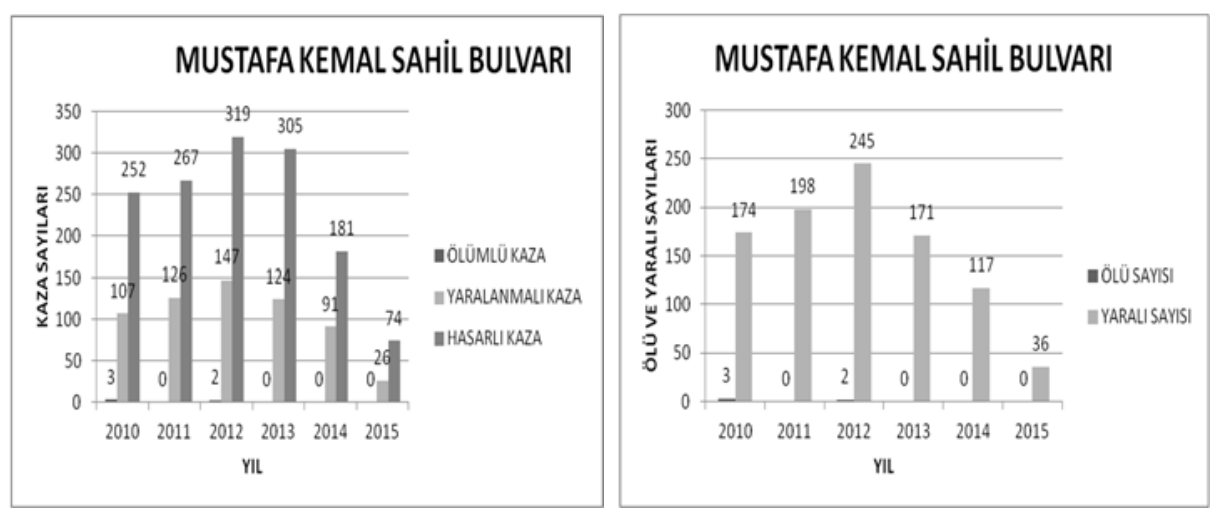

Şekil 13. Mustafa Kemal Sahil Bulvarı'na ait kaza verileri

\section{MALIYYET ANALİí}

Seçilen istasyon noktalarında iki tip kaplama türü vardır. Bir tanesi yüzey iyileştirme yöntemlerinden biri olan harç tipi kaplama, diğeri ise BSK kaplamadır. Çalışma kapsamında bu iki kaplama türünün malzemeleri, sürtünme dirençleri ve kaplamaların trafik güvenliğine etkisi incelenmiştir. Bunlara ek olarak harç tipi kaplama ve BSK'nın 20 yıllık maliyet analizi yapılmış ve birbirleri ile kıyaslanarak hangisinin daha ekonomik olduğu araştırılmıştır.

Literatür özetinde de belirtildiği gibi, harç tipi kaplamanın yenilenme süresi 4 yıl, BSK kullanılarak yapılan yolların ise 10 yıl olarak kabul edilmiştir. Harç tipi kaplamalardan farklı olarak BSK ile uygulanan yenileme işlemlerinden önce kaplamanın yüzeyinin kazınması gerekmektedir. 


\subsection{Bitümlü Sıcak Karışım Maliyeti}

Asfalt karışımının ana bileşenleri esas olarak agrega ve bitümlü bağlayıcıdır. Ülkemizdeki karayollarının büyük bir bölümünde agrega olarak Yollar Teknik Şartnamesinde belirtilen bir takım standart özellikleri karşılamak koşulu ile ve genellikle birim hacim ağırlığı 2,602,70 ton $/ \mathrm{m}^{3}$ olan Kireçtaşı (Kalker-Dolomit) kullanılmaktadır. Bitümlü bağlayıcının Birim Hacim Ağırlığ da 0,95 ve 1,05 ton/ $/ \mathrm{m}^{3}$ arasında değişmektedir. Bu iki malzemenin belirli agrega granülometrisi (Tip 1-2) ve oranlarında yüksek sıcaklık koşullarında asfalt plentinde karıştırılması ile elde edilen asfalt karışımının birim ağırlığı ise yaklaşık 2,44 ton $/ \mathrm{m}^{3}$ dür ve 1 ton asfalt ile $6 \mathrm{~cm}$ kalınlığında $6,83 \mathrm{~m}^{2}$ asfalt kaplama yapılabilir.

$6 \mathrm{~cm}$ kalınlığında $1 \mathrm{~m}^{2}$ asfalt betonu aşınma tabakası için gerekli Asfalt miktarı:

$1,00 \mathrm{~m}^{2} \times 0,06 \mathrm{~m} \times 2,44$ ton $/ \mathrm{m}^{3}=0,1464$ ton $/ \mathrm{m}^{2}$

1 ton asfalt ile kaplanabilecek alan: 1,00 ton $/ 0,1464$ ton $/ \mathrm{m}^{2}=6,83 \mathrm{~m}^{2}$

\subsection{Harç Tipi Kaplama Maliyeti}

Harç tipi kaplamaların ülkemizde yeni kullanılan yüzey iyileştirme yöntemi olması sebebiyle birim fiyatı analizi henüz bulunmamaktadır. Kıyaslama yapabilmek amacı bu iki kaplama türü için $1 \mathrm{~m}^{3}$ karışım için gerekli malzemeler hesaplanmış ve bu hacim için gerekli malzemelerin maliyetleri Karayolları Genel Müdürlüğü birim fiyat analizi ve Tüpraş 2015 verileri kullanılarak hesaplanmıştır (Çizelge 2 ve Çizelge 3) [18].

Çizelge 2. BSK'nın $1 \mathrm{~m}^{3}$ karışıım birim fiyatı

\begin{tabular}{|c|l|c|c|c|c|c|}
\hline Poz No & Tanımı & Miktarı & $\begin{array}{c}\text { Hacim } \\
\left(\mathbf{m}^{3}\right)\end{array}$ & $\begin{array}{c}\mathbf{1 ~ m}^{\mathbf{3}} \\
\text { Hacim için } \\
\text { gerekli } \\
\text { miktar }\end{array}$ & $\begin{array}{c}\mathbf{2 0 1 5} \\
\text { Birim } \\
\text { Fiyatı }\end{array}$ & $\begin{array}{c}\text { Tutar } \\
\text { (TL) }\end{array}$ \\
\hline KGM/6400-1 & $\begin{array}{l}\text { Asfalt Betonu Aşınma } \\
\text { Tabakası Malzemelerinin } \\
\text { Temini (Kırılmış ve Elenmiş } \\
\text { Ocak Taşı ile) (Tip-1) }\end{array}$ & 1 & 0,370 & 2,7 & 17,54 & 47,36 \\
\hline $04.610 / \mathrm{D}$ & Bitümlü malzeme bedeli & 0,058 & 0,056 & 0,157 & 904,96 & 141,74 \\
\hline \multicolumn{6}{|l|}{ TOPLAM } \\
\hline
\end{tabular}

Çizelge 3. Harç tipi kaplama karışımı $1 \mathrm{~m}^{3}$ karışıım birim fiyatı

\begin{tabular}{|c|l|c|c|c|c|c|}
\hline Poz No & Tanımı & Miktarı & $\begin{array}{c}\text { Hacim } \\
\left(\mathbf{m}^{3}\right)\end{array}$ & $\begin{array}{c}\mathbf{1} \mathbf{~ m}^{3} \\
\text { Hacim için } \\
\text { gerekli } \\
\text { miktar }\end{array}$ & $\begin{array}{c}\mathbf{2 0 1 5} \\
\text { Birim } \\
\text { Fiyat }\end{array}$ & $\begin{array}{c}\text { Tutarı } \\
\text { (TL) }\end{array}$ \\
\hline KGM/6400-2 & $\begin{array}{l}\text { Asfalt Betonu Aşınma } \\
\text { Tabakası Malzemelerinin } \\
\text { Temini (Kırılmış ve Elenmiş } \\
\text { Ocak Taşı ile) (Tip-2) }\end{array}$ & 1 & 0,370 & 2,7 & 17,54 & 47,36 \\
\hline $04.611 / 1 \mathrm{D}$ & $\begin{array}{l}\text { Katyonik Asfalt Emülsiyonu } \\
\text { (CSS-1 Tipi) Emülsiyon } \\
\text { malzeme bedeli }\end{array}$ & 0,140 & 0,135 & 0,146 & 1414,50 & 205,95 \\
\hline
\end{tabular}


Bir metreküp malzeme ile BSK için kaplama kalınlığı $6 \mathrm{~cm}$, harç tipi kaplama kalınlığı $8 \mathrm{~mm}$ alınarak birim $\mathrm{m}^{2}$ bulunmuştur. Elde edilen $1 \mathrm{~m}^{3}$ maliyetler kaplama kalınlığ 1 ile $1 \mathrm{~m}^{2}$ maliyetlere çevirilmiştir (Çizelge 4).

\section{Çizelge 4. Kaplamaların birim $m^{2}$ fiyatları}

\begin{tabular}{|c|c|c|c|c|}
\hline Kaplama Cinsi & $\begin{array}{c}\text { Tabaka } \\
\text { Kalınlığı } \\
(\mathbf{c m})\end{array}$ & $\begin{array}{c}\mathbf{1}^{\mathbf{2}} \text { ile kaplama } \\
\left.\text { yapılabilecek alan } \mathbf{( m}^{\mathbf{2}}\right)\end{array}$ & $\begin{array}{c}\text { Birim Fiyatı } \\
\left(\mathbf{T L} / \mathbf{m}^{\mathbf{3}}\right)\end{array}$ & $\begin{array}{c}\mathbf{1 ~ m}^{\mathbf{2}} \\
\text { Birim Fiyatı (TL) }\end{array}$ \\
\hline Bitümlü Sıcak Karışım & 6 & 16,67 & 189,10 & 11,35 \\
\hline Harç tipi kaplama & 0,8 & 125 & 253,31 & 2,03 \\
\hline
\end{tabular}

\subsection{Harç Tipi Kaplama ve BSK Yenileme İşlemlerinin 20 Yılık Maliyet Analizi}

Farklı tür kaplama yenileme işlemlerinin 20 yıllık maliyet analizi yapıldığında başlangıç olarak yapılan masraf tüm yenileme işlemleri için aynıdır ve BSK maliyeti kadardır. BSK'nın ortalama yenileme süresi olan 10. yılın sonunda yenileme türüne göre yapılan maliyetler değişmektedir. BSK kullanılarak yapılan yenileme işlemlerinde harç tipi kaplamadan farklı olarak kaldırım kotlarının düşmemesi ve rögar kapakların yol kotunun altında kalmaması için mevcut kaplamanın kazınması gerekmektedir. Çizelge 5'de bitümlü sıcak karışımın $1 \mathrm{~m}^{2}$ için birim kazıma maliyet hesabı bulunmaktadır.

Çizelge 5. Bitümlü Sıcak Karışım $1 \mathrm{~m}^{2}$ kazınma birim fiyatı

\begin{tabular}{|c|c|c|c|c|}
\hline Poz No & Tanımı & $\underset{\left(\mathbf{m}^{3}\right)}{\text { Hacim }}$ & $\begin{array}{l}2015 \text { Birim } \\
\text { Fiyatı } \\
\left(\mathrm{TL} / \mathrm{m}^{3}\right)\end{array}$ & $\begin{array}{l}1 \mathbf{m}^{2} \\
\text { Birim Fiyatı } \\
\quad(\mathrm{TL})\end{array}$ \\
\hline KGM/40.130 & $\begin{array}{l}\text { Asfalt kazıma makinası ile her cins } \\
\text { bitümlü karışım kaplamaların } \\
\text { kazılması }\end{array}$ & 1 & 58.70 & 3.52 \\
\hline
\end{tabular}

Harç tipi kaplamanın yenileme süresi 4 yıl olarak alındığında geriye kalan 10 yıl içerisinde 3 kez yenilenmesi gerekmektedir. BSK için ise 10. Yılın sonunda kullanılmaz hala gelen mevcut kaplamanın kazınması işleminden sonra bir kez daha dökülmesi yeterli olacaktır. $\mathrm{Bu}$ durum Şekil 14'de daha net görülebilmektedir.

$\mathrm{Bu}$ durumda yenileme işlemi için BSK kullanılan $1 \mathrm{~m}^{2}$ kaplamanın 20 yılın sonundaki toplam maliyeti:

$$
\begin{gathered}
\text { 11,35 TL (başlangıç maliyeti) } \\
\text { 3,52 TL (kazıma masrafi) } \\
\text { 11,35 TL (yenileme masrafi), }
\end{gathered}
$$

Toplam 26,22 TL olarak bulunur. 
Yenileme işlemi için harç tipi kaplama kullanılan $1 \mathrm{~m}^{2}$ kaplamanın $20+2$ yıl sonundaki toplam maliyeti:

11,35 TL (başlangıç maliyeti)

2,03 x $3 \mathrm{kez}=6,09 \mathrm{TL}$ (3 kez yapılacak harç tipi kaplama maliyeti)

Toplam 17,44 TL olarak bulunur.

Yapılan araştırmanın sonunda da görülmüştür ki 20 yıllık süre için harç tipi kaplama ile yapılan yenileme işlemleri BSK kullanımına nazaran \%40 oranında daha ekonomiktir. Sadece bakım maliyeti olarak karşılaştırıldığında ise BSK'ya oranla Harç tipi kaplamalar yaklaşık 2,5 kat daha ekonomiktir.

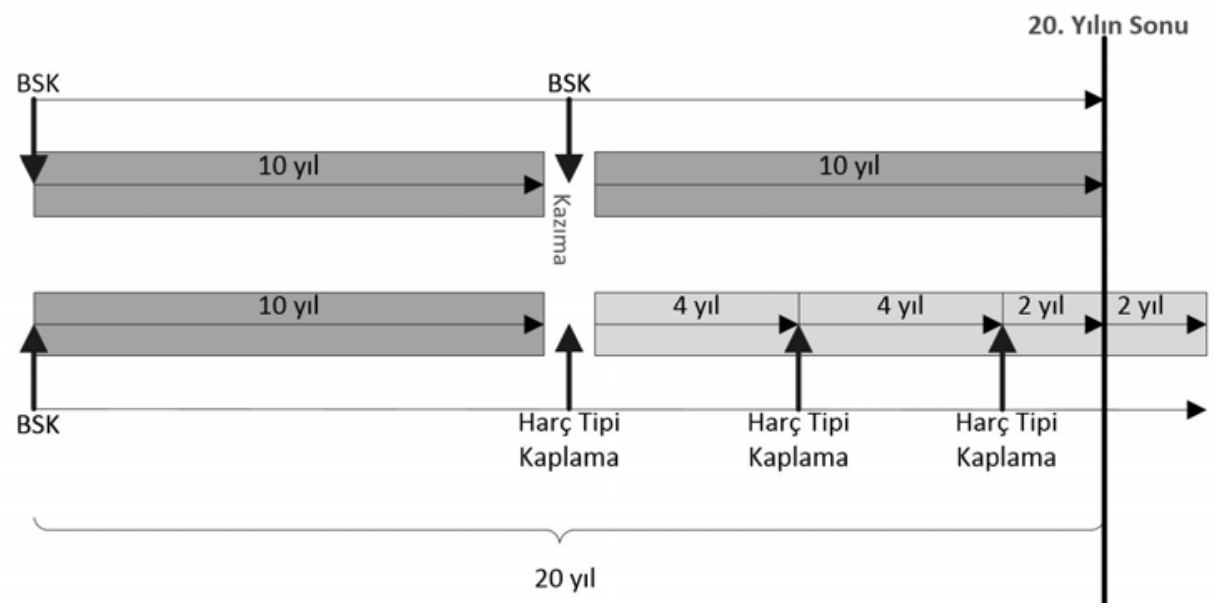

Şekil 14. BSK ve harç tipi kaplamanin 20 ylllık maliyet analizi

\section{SONUÇ VE ÖNERILLR}

108M293 no'lu Tübitak projesinin istasyon noktaları arasından seçilen, harç tipi kaplama yapılan istasyonlara ait kum yama deneyi ve dinamik sürtünme ölçer cihazı mevcut eski verileri güncel saha deneyleri ile karşılaştırıldığında, kaplamadaki yol yüzey dokusunun imalat yılı olan 2013 yılından itibaren çok önemli miktarda arttığı gözlemlenmektedir. Yol yüzey dokusunda meydana gelen bu artışın sürtünme direncini de arttığı görülmektedir. Yol yüzey dokusu kaplamanın sürtünme direncini etkilemektedir.

Çalışma kapsamında önce-sonra etüdü ile birlikte güncel verileri de karşılaştırmak amacıyla aynı güzergâh üzerinde harç tipi kaplama imalatı yapılmış ve yapılmamış istasyonlarda yapılan deneyler sonucunda, yol yüzey dokusunun; imalat yapılan istasyonlarda yapılmayan BSK kaplamalara göre daha yüksek değerlere sahip olduğu görülmüsstür. Ayrıca bu değerin ağır trafik yüküne maruz kalan bölgelerde bile imalat yapılmayan bölgelere göre 2 kat daha büyük değere sahip olduğu tespit edilmiştir. 
Kum yama deneyi ile elde edilen ortalama doku derinliği (MTD) ile tek başına kaplamanın yüzey dokusunun güvenilirliğini belirlemek yeterli değildir. Deney sonuçları, deneyi yapan operatöre, havanın yağışlı ve/veya rüzgarlı olmasına bağlı olarak değişkenlik gösterebilmektedir. Kaplama hizmet kalitesi değerlendirilirken servis ömrü süresince $F(60)$ değerindeki değişimin incelenmesinin daha sağlıklı olacağı düşünülmektedir.

Yüzey iyileştirme uygulamalarının trafik güvenliği üzerinde etkisinin araştırılması için İzmir Bölge Trafik Müdürlügü’’nden temin edilen kaza verileri, yüzey iyileştirilmesi yapılmadan önceki ve sonraki durum, yol yüzey dokusu ve DFT deney verileri 1şı̆ı̆ında karşılaştırıldığında; harç tipi kaplama imalatının sağladığı yüzey dokusu sayesinde yol güvenliğinin önemli miktarda arttığı görülmektedir. İstasyon noktalarında yüzey iyileştirme işlemi öncesi ve sonrasında yaşanan kazalar incelendiğinde, yenileme çalışmasından sonra pürüzlülük değerleri artan yollarda kazaların önemli oranda azaldığı görülmüştür. Ancak, trafik kaza tutanaklarında fren mesafelerinin yanında, kazanın meydana geldiği yol yüzeyinin pürüzlülüğünün de belirlenmesi ve bu amaçla hızlı ve etkin bir yöntemin kullanılması gerekliliği de ortadadır. Trafik kaza tutanaklarının, trafik kazalarının sağlıklı ve geniş çaplı araştırmalarının yapılabilmesi amacıyla oluşum nedenlerini daha sağlıklı yansıtabilecek şekilde yol yüzey durumu ile ilgili bilgileri de içerecek şekilde tutulması sağlanmalıdır.

Tasarım kriterlerini sağlayan ancak yüzey doku özellikleri kötü olan yollar, araç tekerleklerinin kaplama yüzeyi ile iyi aderans sağlanmaması nedeni ile kaza oluşumu açısından risk teşkil etmektedir. Bu sebeple yüzey doku derinlikleri ve sürtünme değerleri de tasarım kriteri olarak değerlendirilmelidir.

BSK kaplamaların 20 yıllık ömür-döngü maliyetleri incelendiğinde, bakım çalışmalarının yeni bir BSK kaplaması yerine harç tipi kaplama yapılması durumunda yaklaşık $\% 40$ daha ekonomik olduğu hesaplanmıştır. Sadece bakım maliyeti olarak karşılaştırıldığında ise BSK'ya oranla Harç tipi kaplamalar yaklaşık 2,5 kat daha ekonomiktir. Kaza oranlarındaki azalma ve daha düşük maliyetler de göz önüne alındığında yüzey iyileştirme yöntemlerinden olan harç tipi kaplamaların bitümlü sıcak karışıma göre tercih edilebileceği görülmektedir.

Çalışma sonuçlarından da görülebileceği gibi, harç tipi kaplamalar gerek ekonomik gerek güvenlik gerekse performans açısından BSK'ya kıyasla daha iyi sonuçlar vermektedir. İzmir ilinde yaygın olarak kullanılmayan harç tipi kaplamaların yol yüzey özelliklerini iyileştirme çalışmaları için uygulanması önerilir.

\section{Teşekkür}

Bu çalışmanın gerçekleştirilmesindeki katkılarından dolayı DEÜ Fen Bilimleri Enstitüsü'ne teşekkür ederiz.

Bu çalışma DEÜ BAP 2015 KB FEN 029 nolu proje kapsamında desteklenmiştir. DEÜ BAP Koordinatörlügüne desteklerinden dolayı teşekkür ederiz.

Çalışma kapsamında yapılan tüm ölçüm ve gözlemler sırasında verdikleri destekler için, İzmir Emniyet Müdürlüğü, İzmir Trafik Denetleme Şube Müdürlüğü ve İzmir Büyükşehir Belediyesine teşekkür ederiz. 


\section{Kaynaklar}

[1] Kane, M., \& Cerezo, V. (2015). A contribution to tire/road friction modeling: From a simplified dynamic frictional contact model to a "Dynamic Friction Tester" model. Wear, 342, 163-171.

[2] Praticò, F. G., Vaiana, R., \& Fedele, R. (2015). A study on the dependence of PEMs acoustic properties on incidence angle. International Journal of Pavement Engineering, 16(7), 632-645.

[3] Dong, Q., \& Huang, B. (2012). Evaluation of influence factors on crack initiation of LTPP resurfaced-asphalt pavements using parametric survival analysis. Journal of Performance of Constructed Facilities, 28(2), 412-421.

[4] Tarefder, R. A., Ahmad, M., \& Hossain, M. I. (2016). Pavement maintenance procedures with and without milling materials. International Journal of Pavement Research and Technology, 9(1), 20-29.

[5] Rado, Z., Yager, T.J., Wambold, J.C. ve Hall, J.W., (2006). Guide for pavement friction, final report preraped for NCHRP, Project No:1-43.

[6] International Organization for Standardization (ISO), (1997). Characterization of pavement texture by use of surface profiles, part 1: Determination of mean profile depth, ISO 13473-1.

[7] Fuentes, L., Gunaratne, M., de León Izeppi, E., Flintsch, G., \& Martinez, G. (2012). Determination of pavement macrotexture limit for use in International Friction Index model. Transportation Research Record: Journal of the Transportation Research Board, (2306), 138-143.

[8] Buddhavarapu, P., Smit, A. F., \& Prozzi, J. A. (2015). A fully Bayesian before-after analysis of permeable friction course (PFC) pavement wet weather safety.Accident Analysis \& Prevention, 80, 89-96.

[9] Montella, A., \& Imbriani, L. L. (2015). Safety performance functions incorporating design consistency variables. Accident Analysis \& Prevention, 74, 133-144.

[10] Li, P., \& He, J. (2016). Geometric design safety estimation based on tire-road side friction. Transportation Research Part C: Emerging Technologies, 63, 114-125.

[11] Wang, Y., Wang, G., \& Mastin, N. (2011). Costs and Effectiveness of Flexible Pavement Treatments: Experience and Evidence. Journal of Performance of Constructed Facilities, 26(4), 516-525.

[12] Hajj, E., Loria, L., Sebaaly, P., Borroel, C., \& Leiva, P. (2011). Optimum time for application of slurry seal to asphalt concrete pavements. Transportation Research Record: Journal of the Transportation Research Board, (2235), 66-81.

[13] Şengöz, B., Tanyel, S., Topal A., Gümüsstekin, Ş. ve Ağar, E. (2012). Yol kaplama yüzeylerinin mikro-makro pürüzlülüğünün görüntü analiz yöntemleri ile belirlenmesi, sonuçların trafik güvenliği açısından değerlendilirmesi. MAG 108M293 no'lu TÜBİTAK Projesi, Ankara. 
[14] American Standard of Testing Materials. (2005). ASTM E1911-09, Standard test method for measuring paved surface frictional properties using the dynamic friction tester. ASTM International, Volume 04, West Conshohocken, PA, United States.

[15] Rado, Z., Analysis of texture models, PTI Report No. 9510, Pennsylvania Transportation Institute, Penn State University, State College, Pennsylvania, 1994.

[16] Hall, J.W., Smith, K.L, Glover L.T., Wambold, J.C., Yager, T.J., Rado, Z., Guide for pavement friction, NCHRP, Project No:01-43, 2009.

[17] American Standard of Testing Materials. (2011). ASTM E 1960-07, Standard practice for calculating international friction index of a pavement surface. ASTM International, West Conshohocken, PA, United States.

[18] İzmir Büyükşehir Belediyesi, (2013). İzbeton A.Ş 60118 No'lu ihale, İzmir ili muhtelif cadde ve sokaklarda çift kat harç tipi asfalt kaplama (Slurry Seal) yapılması yapım işi teknik şartnamesi. 